\title{
Integrating Business Strategy and Sustainability Development of the Society: A Case of Aqua Company in Indonesia
}

\author{
Roseno Aji Affandi \\ International Relations Department \\ Bina Nusantara University \\ Jakarta, Indonesia \\ roseno.affandi@binus.ac.id \\ Elisa Anastasia \\ International Relations Department \\ Bina Nusantara University \\ Jakarta, Indonesia
}

\author{
Aditya Permana \\ International Relations Department \\ Bina Nusantara University \\ Jakarta, Indonesia
}

Tirta Nugraha Mursitama

International Relations Department

Bina Nusantara University

Jakarta, Indonesia

\begin{abstract}
This study reveals the importance of the effect of integration between corporation and society by employing corporation strategy and sustainibility development society as an important driver in acheiving equal and mutual relationship for the participation to develop healthy environment, food safety, small enterprise and the quality of education. This study defines the expansion strategy's motives of the corporation and the character of the surroundings society. Each motives related to the different business strategy toward different stakeholders based on motive of MNC theory, circles of sustainability, triple bottom line and the diamond theory. This research employs qualitative approach, i.e. using questionnaire and in-depth interview in selected area of business operation and society as our primary data, supplied with secondary data from the literature and publicly available data. This research resulted in the integration of society development and business as reasonable strategy to understand both party common interests and needs, government's understanding on the negative impact of business operation to community and prevent public dissatisfaction due to the misinteraction between the business and the people. Consequently, it will create a new economic, politics and social life landscape towards people-oriented in certain area and characteristic.
\end{abstract} Line

Keywords: Business Strategy, Sustainability, Triple Bottom

\section{INTRODUCTION}

Globalization is often said to be a standardization process. This standardization simplifies the process of inter-country interaction, both in exchange of information, technology, trade process, even in the dissemination of science. Based on the development of their knowledge, international relations are constantly moving from the security approach to the economy, of which spearheaded by the Multinational Corporations (MNCs). By globalization, MNC can freely expand from one country to another with the excuse to reduce political risk, and gain new resources, new market share, and other matters related to the expansion of the MNCs' operations.

The proponents of the standardization approach, such as Levitt and Ohmae, view the globalization trends in the world as the primary driving force behind greater market similarity, more technological uniformity, and higher convergence of consumer needs, tastes, and preferences (Levitt, 1983; Ohmae, 1985). They also claim that standardization is further facilitated by the growth of international communication channels, the emergence of global market segments, and the appearance of the Internet. They posit that such a strategy can offer a number of benefits: (a) significant economies of scale in all value-adding activities, particularly in research and development, production, and marketing; (b) the presentation of a consistent corporate/brand image across countries, especially in light of the increasing consumer mobility around the world; and (c) reduced managerial complexity due to better coordination and control of international operations (Levitt, 1983; Douglas and Craig, 1986; Yip, Loewe, \& Yoshino, 1988).

To some extent, Multinational Corporations (MNC) is a company or business organization that expanding abroad along with Foreign Direct Investment (FDI) theory. FDI itself is an expansion of an MNC to a certain country region with an approach to the international financial system, either through direct investment strategies or building a strategic alliance network (Cohen, 2007). Theoretically, there are four main motives of MNCs expansion, that are: market seeker motives, resource seeker motives, efficiency seekers and Strategic Asset seekers motives. The main purpose of these motives is to improve the competitiveness of companies or organizations (Dunning and Lundan, 2008).

Along with the FDI, MNC as an entity of the company organization consciously and directly related to the state and society. It is necessary to have a method to synergize the interests of the company with all its shareholder elements, the country with all the components of the policy, policy maker and the factors that influence it, as well as the communities which will directly impacted by the positive and residual effects of FDI activities of a company organization.

The main focus of this research is to observe the process of creating value-added companies by identifying the company's strategy and analyzing the impact of CSR program 
implementation. To do so, we examine the strategy of the company's CSR implementation to the surrounding community, in this case the bottled mineral drinking water manufacture company, which branded "AQUA", and the surrounding community in Cicurug, Sukabumi, West Java, Indonesia where the factory is established by conducting a field study. Our hypothesis, if the company can integrate corporate strategy with the theory of three bottom line approach and circles of sustainability theory, then the sustainable prosperity between the company, society and the stakeholders will be achieved.

\section{LITERATURE REVIEW}

In 2015 and 2016, more than 50 percent contributors to the capital turnover, both capital inflow and outflow come from G20 and APEC group (UNCTAD, 2017). These capital flows migrate due to FDI activities from the MNCs, either through corporate actions in the form of acquisitions, mergers, development of production capacity or opening of distribution and marketing network. There are 5 manufacturing industries that contribute 70 percent to the whole type of manufacturing industry. These industries are chemical, food and beverage producers, electronics, motor vehicles and petroleum and mineral exploration.

Apparently some of these industries particularly have good motive as market and efficiency seeker. They function and allocate their host country as a center for production efficiency as well as market development, in our case, as Danone did with Aqua. Danone with Aqua is a manufacturing company on beverage industry while in the same time acting as market seeker. On the othe hand service industry on wholesale and retail trade contribute $43 \%$ of service industry's FDI (UNCTAD, 2017)

FDI affects the economic structure of the host country, especially developing countries. The effect is wider than the impact to the longstanding or new companies. FDI also affected to a country's economic growth, revenue generation, new jobs opening, increasing people's purchasing power, and so on. Apart from the economic aspect, FDI in its interaction with the state political and society also has the ability to influence or be influenced. FDI is expected to excel the healthy and positive interaction among county's stakeholders.

In this light, there are related ethical and social issues that are often crucial for MNC strategies and long-term success. This connects to what may be called "moral standards" which include for example, basic rights of freedom, movement, free speech, and nondiscrimination issues. Those standards can be viewed from a universal, relativistic, or social contracts perspective (Donaldson and Dunfee, 1999).

This ethical and social issues are need to be consider because in the current era of globalization MNC may become more dominant than state. In the process, FDI and MNC cannot be separated, but it is always raising question about what contribution they can give to the surrounding communities, especially in the economic, social and political spheres. The Implication of FDI and MNC from home country to host country, are not merely in the business and economic aspects only, but the socio-political dimensions as well.

To optimize the synergy between home and host country, there are two considerations in measuring a company's success, namely the interests of shareholder and stakeholder.
Shareholder (main stakeholder) is the main actor of the establishment of a company, because Shareholder is the investor of the company. This make them have power to make decision for a company, while simultanesously they bear the risk of capital loss. On the other hand, Stakeholders are either internal or external person, group or party who has direct relationship with the company. Consequently, they have role in determining the company's success. Stakeholders can be the employees, consumers, suppliers, environment, as well as communities, organizations, or individuals who have relationships and interests of the company.

A stakeholder approach to business is ideally suited to integrate business, ethics and societal considerations, because Stakeholder theory has its concern on the value creation. Managers needed to understand the concerns of shareholders, employees, customers, suppliers, lenders and society, in order to develop objectives that stakeholders would support. This support was necessary for long term success. Therefore, management should actively explore its relationships with all stakeholders in order to develop business strategies (Freeman and Velamuri, 2002).

In this light, along with the idea of "moral obligation", a MNC that operated in a particular country can not be said as successful if it does not create congenial values in their operation. Therefore the concept of Corporate Social Responsibility (CSR) arises and give a company an account of responsibility to its stakeholders. Now it is widely accepted that the practice of Corporate Social Responsibility (CSR) is considered as an integral part of business' operation. Gherghina and Simionescu (2015) points out that CSR could be thought as a pillar of the company since through,

“...its practices it represents a commitment to its stakeholders, being with an ear on the ground, and with the other one on company all needs. The measurement of CSR success is associated with the sustainability of the program, measured by changes or transformation in people's behavior in company surrounding area" (Gherghina and Simionescu, 2015).

By CSR, the company welcomes the social activities of the environment, the surrounding community with the aim of making their business better and more secure. With confidence, the company believes that its participation in conducting CSR can simultaneously improve the people's welfare and company's performance (Bhattacharya, Sen and Korschun, 2012). In this vantage point, CSR program is a long-term investment for a company to the growth and sustainability of the company. This enhancing the company brand image and simultaneously as the mean of profit making. Thus, CSR program is a form of corporate commitment in their accountability while on the other hand support the creation of sustainable development (Robins, 2015).

\section{RESEARCH METHOD}

This research employs mixed methods of quantitative and qualitative research. We conducted a field research with a sample consist of 100 people, and conduct an indepth analyses to various sources of information and data obtained to examine research problems. Primary data is collected from the field observations and interview to the various Stakeholders of PT AQUA Golden Mississippi factory, on J1. Raya Siliwangi No. 70, Cicurug, Sukabumi, local government, and 
direct observation to Sukabumi, Cicurug District. These data would supported by secondary data from various credible public data sources such as journal articles, news articles, and documents from the company's official web concerned with the topic of research. Both data set is analyzed with the lens of triple bottom line theory and circles of sustainability theory to describe the impact of the value creations by AQUA company to their surrounding community and stakeholders based on its CSR program implementation.

We took samples to the community around the district Cicurug, namely the Cicurug village as many as 17 communities, and 3 local government; Mekarsari as many as 8 communities; The objects of 24 communities, and 2 local governments; Nanggerang as many as 14 communities; Nyangkowek for 5; Bangbajang of 9; Purwasari of 7; Search for 5; and Tenjoayu for 8 communities. There are at least 12 interview questions to the Cicurug district government, which then the authors divide into three main categories: (1) Question 1-5 is company introduction, (2) Question 6-8 is program utilization, (3) Question 9-12 is a question of direct benefits. The other respondent in Cicurug area are traders (9), security guard (1), journalist (1), activist (2), student (2), receptionist (1), and housewife (1).

AQUA Group is a local Indonesian company that established in 1973 under the name of PT AQUA Golden Mississippi (PT AGM), under PT Tirta Investama, the pioneer of the first mineral water company in Bekasi, Indonesia. In 1998 AQUA Group acquired by French Company DANONE. This merger impacted on the improvement of the product quality and putting AQUA Group as the largest bottled water producer (AMDK) in Indonesia. DANONE increased its stake in PT Tirta Investama from $40 \%$ to $74 \%$ in 2001 which became the majority shareholder of AQUA Group.

With awareness of the brand image attached to the company, the company is also aware of the balance between the company and society, especially in the water source environment as one of the requirements of the creation of sustainable growth. AQUA Group implement a communitybased approach by running its social programs by creating close partnerships with communities, local governments and other stakeholders (AQUA, 2017).

Furthermore, AQUA also participates in supporting the Millennium Development Goals (MDG). In September 2000 the largest ever gathering of heads of state ushered in the new millennium by adopting the UN Millennium Declaration. The declaration, endorsed by 189 countries, was then translated into a roadmap setting out goals to be reached by 2015 . The eight goals in the section on development and poverty eradication are known as the Millennium Development Goals. They build on agreements made at major United Nations' conferences of the $1990 \mathrm{~s}$ and represent commitments to reduce poverty and hunger, to tackle ill health, gender inequality, lack of education, lack of access to clean water, and environmental degradation (Haines and Cassels, 2004).

To fulfill this goals, AQUA providing access to clean water for the surrounding community with Water Access, Sanitation and Hygiene (WASH) as one of their CSR strategy program. The program aims to improve public access to clean water and provide healthy sanitation facilities; as well as increasing knowledge and awareness of surrounding communities on hygiene and sanitation implementation. This program gets a lot of support from other parties, such as SMEs (Micro, Small, Medium Enterprises); NGOs (NonGovernmental Organizations), and the Government in Sukabumi District, who participated in donating garbage transport vehicles, and additional water meter accessories as well as transportation costs of transporting pipes to water sources.

\section{THEORETICAL FRAMEWORK}

Based on his theory in the operation of a company proclaimed by John Elkington (1997) states there are three main factors commonly called Triple Bottom Line, consist of: (1) People, the main focus of the establishment of a company is human; (2) Planets, companies must actively participate in safeguarding and improving the natural environment, not just the exploitation of natural resources for profit; (3) Profit, which is a key element that can bridge between a business (Fontaine, 2013).

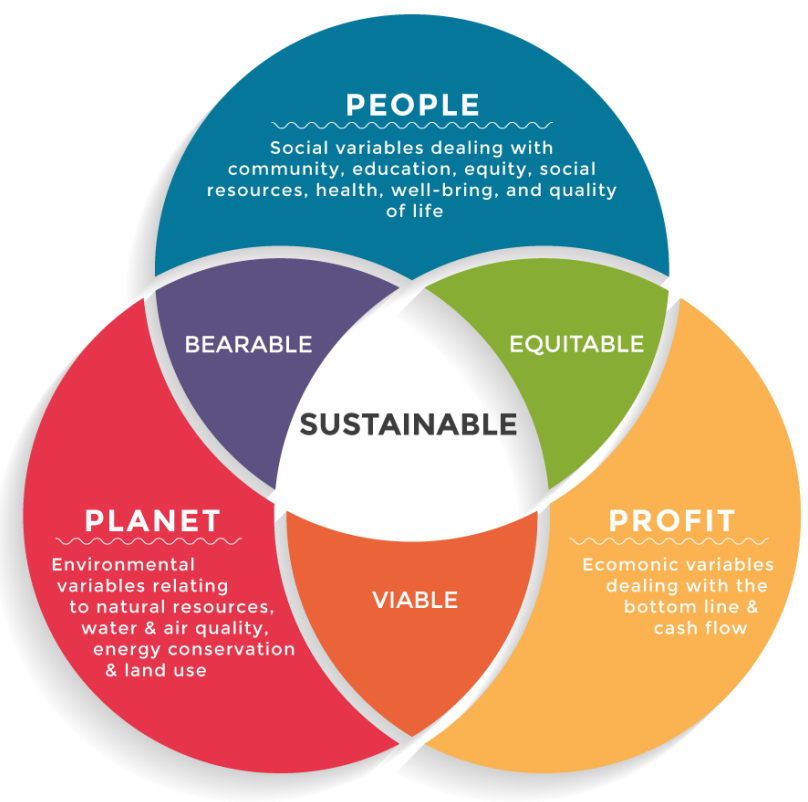

Figure 1 CSR triple bottom line

Source: csrambassadors.com

(http://www.csrambassadors.com/corporate-socialresponsibility-csrambassadors/triple-bottom-line/)

Our second framework is the circles of sustainability theory. This is a theory that assesses the sustainability and management of projects to be directed socially sustainable outcomes. It is intended to deal with the seemingly difficult problem of understanding the underlying problems of social life that must take into account four things: economics, ecology, politics, and culture. In these considerations there are at least five major focuses on the implementation of CSR in one place, namely: Environment, Health, Food, Education, and Empowerment.

Within the circle of sustainability theory (Sustainability Theory), the crucial point are the initiative in the form of 
responsibility of a company and seeks to prioritize and integrate social responses primarily to environmental and cultural issues. On the basis of the use of the term "sustainability" it results in a dependent social condition; For example, an agreement or economic policy, and cultural practices commonly referred to as sustainable. This concept of sustainability frames ways in which environmental problems jeopardize the conditions of economic, political, and ecological systems.

1. Economy as an opportunity, usually in the form of capital. According to the classic definition formulated by Robert Solow, it requires us to commit to sustainability with future investment goals. In other words we will get new opportunities for the same or greater value.

2. Politics propose to maintain the social system by realizing the human dignity. This is because it is feared that environmental problems can endanger human dignity. So this political aspect is one of the important things because it focuses on the environmental threats to human life.

Other strategies in this model, such as agrarianism or ecology involving more substantive visions of human good. Ultimately, this model recommends to maintain the necessary cultural conditions for the realization of ecological personality, civic identity, or even personal belief through ecological membership.

\section{RESULT AND ANALYSIS}

The Indonesian Bottled Drinking Water Company (Aspadin) association says consumption of AMDK grows $12.5 \%$ per year during 2009-2014. In 2009, AMDK sales volume reached 12.8 billion liters, and increased to 23.1 billion liters by 2014 (marketeers.com). Currently, there are about 500 companies engaged in the AMDK industry, which is fragmented into small and local companies. However, largescale enterprises are becoming the national market leader of AMDK. According to Goldman Sachs research, AQUA from DANONE Group controls $46.7 \%$ of AMDK market share, followed by Tirta Bahagia (Club) 4\%, Tangmas (2 Tang) $2.8 \%$, PT Santa Rosa Indonesia (Oasis) 1.8\%, Triusaha Mitraraharja (Super O2) 1.7\%, and Sinar Sosro (Prima) $1.4 \%$ (marketeers.com). From this data it is evident that PT AQUA holds the most market share for AMDK.

\section{A. Internal Factors of MNC. The Strategy of MNC:}

PT AQUA Golden Mississippi company holds a vision in being the largest volume factory and best SQCDME performance in AQUA Group in 2018. In establishing this vision, the company establish a mission, e.g. a series of sentences that state the purpose or reason of the existence of the organization that contains what is provided by a company to the community, either in the form of products or services (Wheelen, 2006). These sentences abbreviated as SQCDME, which stands for Safety-Quality-Cost-Delivery-MotivationEnvironment.

1. Safety. Achieving safety culture level Interdependent score WISE 65, Zero Accident, Zero PAK and realization of life balance.

2. Quality. Achieve the best quality at every stage of the process through the active role of each stakeholder.
3. Cost. Achieve low operating costs at each stage of the process.

4. Delivery. Achieve $100 \%$ PSL with service and product delivery as per customer's expectation.

5. Motivation. Achieving team performance independently and professionally through competency enhancement of all stakeholders.

6. Environment. Achieving Proper Gold through a sustainable Comunity Development program.

Table 1 PT AQUA Golden Mississippi Mekarsari Factory of June 2017

\begin{tabular}{|c|c|}
\hline Ownership & $\begin{array}{l}\text { Danone } 74 \% \text {, PT Tirta } \\
\text { Investama } 26 \%\end{array}$ \\
\hline Total Equity/Year & $539,290,464,951$ \\
\hline $\begin{array}{l}\text { Number of Shares in } \\
\text { Sheet }\end{array}$ & $297,360,000$ \\
\hline $\begin{array}{l}\text { Number of Shares } \\
\text { per sheet }\end{array}$ & 1,813 \\
\hline Starting Operation & October 1994 \\
\hline Number of Factories & $\begin{array}{l}17 \text { (under the name PT Tirta } \\
\text { Investama) }\end{array}$ \\
\hline Employees & $\begin{array}{l}12,000 \text { persons in } 17 \\
\text { factories }\end{array}$ \\
\hline $\begin{array}{l}\text { Annual Production } \\
\text { Capacity }\end{array}$ & $\begin{array}{l}1.665 \text { billion liters of } \\
\text { water/year }\end{array}$ \\
\hline $\begin{array}{l}\text { Capacity sales } \\
\text { volume/Year }\end{array}$ & $\begin{array}{l}1,500 \text { billion liters of } \\
\text { water/year }\end{array}$ \\
\hline Active CSR Program & $\begin{array}{l}\text { WASH (Water Access, } \\
\text { Sanitation and Hygiene), } \\
\text { Conservation (Wells } \\
\text { Absorption, Biopori, Tree } \\
\text { Cultivation), and Economy } \\
\text { Development } \\
\text { (empowerment in the form } \\
\text { of capital to MSMEs) }\end{array}$ \\
\hline $\begin{array}{l}\text { CSR program } \\
\text { location }\end{array}$ & $\begin{array}{l}\text { Cicurug } \quad \text { Babakan Pari, } \\
\text { Cicurug, } \\
\text { Nyangkowek, } \\
\text { Tangkil, Carsarigin, } \\
\text { Nanggerang, Benda }\end{array}$ \\
\hline CSR expense & Over 100 Million rupiah \\
\hline
\end{tabular}

Based on this data, DANONE as its majority shareholder for PT AQUA. The host country in Indonesia which Tirta 
Investama as minority share holder. The motive of PT AQUA as a MNC is a company that invest and operates as resources seeker, market seeker and strategic asset seeker. With the approach of FDI in the form of acquisition of shares from the old owner. They take the source of material in the form of water from Indonesia, then in production and sold in the Indonesian market as well. DANONE as the majority shareholder did not take corporate action from the start of company pioneering. They started as small investors who then went on to become the majority holder. This transformation process is not as easy as buying stocks. Many values that are intangible and cultural need to improve the process of adaptation between new management with customers, vendors, employees, government and social environment. Managerial change became the key success to DANONE'S acquisition.

On the other hand, this managerial change also bring about the new direction of CSR as the tool of value creation to acuquire the surrounding community. The key is in the harmony between internal values of the company and the society. Internal values of the company rely on the harmonization of individual values of the employees along with the corporate vision. The relationship between stakeholder groups and the firm must be based on mutual trust and cooperation, as opposed to opportunism, in order to facilitate competitive advantage. This introduces the notion of personal values as drivers of CSR (Hemingway and Maclagan, 2004).

Figure 1 explains the relationship of internal values individual employee with the corporate vision. The combination of Individual values and corporate vision translated to Corporate Strategic including the CSR program as well. CSR becoming one of the succes factor in Business Strategy. The Framework helps the corporate to integrating the Strategic and Society Development. With a structured and parallel approach, the integration of work and culture can go hand in hand. One method is to create a project together, such as the CSR program. For internal company, this will affect the reduction of awkwardness and ease the process of adaptation. Task that come into contact with society but also affect the share values between individual employees and employees, both of which are from old companies with employees from new companies. and from employees with the community.

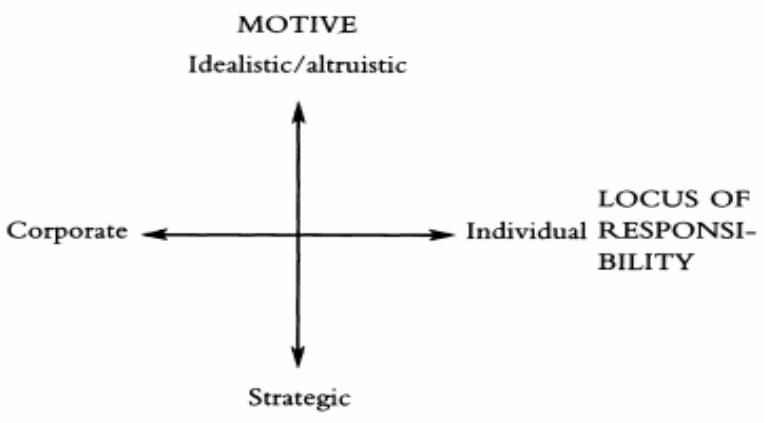

Figure 1 Strategic Framework and CSR.

\section{Source: Hemingway and Maclagan, 2004}

To integrate corporate values, all employees and society, the AQUA group has an "AQUA Lestari" program that has been developed since 2006. AQUA Lestari has four main pillars: water conservation and environment, environmentally friendly company practices, product distribution management, and community engagement and empowerment. In addition, AQUA also participates in supporting the Millennium Development Goals (MDGs) program through contributions in providing access to clean water for local communities through the Water Access, Sanitation and Hygiene (WASH) program or commonly referred to as Clean Water Access and Environmental Health. The WASH program has been implemented with the involvement of stakeholders such as communities, local NGOs and government. In other words, this WASH program supports the MDGs program launched by the UN in fighting poverty and hunger in various parts of the world.

With this CSR program, it involves not only CSR and community divisions alone. It turned out to be the pride of the managers to be involved in helping solve this community problem. Old and new workers mingle together to help the surrounding community. Make employee meetings more relaxed and relaxed. creating a less formal atmosphere of communication. brings together trust and pride.

B. External Factors of MNC: Community Engagement through CSR

We observe the impact of CSR program from PT AQUA by creating a tabulation from the questionnaire distributed to 100 respondents, supplied with interview to local governments and communities ranging from the office district, village to the neighborhood level (RT/Rukun Tetangga). In addition, interviews are also conducted to traders, perpetrators of SMEs, motorcycle taxi services, transportation, boarding house with a radius of a sub-district (kecamatan) of the target area.

In summary, the authors get a lot of stories from this Cicurug area, among others: from 17 respondents, there are at least 9 respondents who are dissatisfied with the existence of PT AQUA. This is because the locals who lived for a long time in the area felt that Cicurug had changed, as it became warmer and difficult in getting water. Even an activist claimed that AQUA had been carrying out a water theft that had lasted for 22 years. This is due to the absence of SIPA (Underground Licensing Permit) and must be closed. On the other hand, there are a number of respondents who are very happy with CSR program because they were hired in PT AQUA company. Furthermore, although the trucks circulations from PT AQUA are damaging the streets, the company always have had the road repaired. On the other hand, there are also 8 respondents who answer in a neutral way, which means PT AQUA is a good company, but they claim that CSR programs conducted by PT AGM do not really have any profound effect on them except congestion because of the company trucks traffic.

From the observation to the local government, the interviews to three local officials, Iman Sugiman S. Ip (Secretary of the District), Ujang Komaruddin (Kasi TRANTIB/security and order) and Ocit (Kasi Government), we ask at least 13 interview questions that the authors ask the Cicurug District Government, which then the authors divide into four main categories: (1) Question 1-5 is Corporate introduction, (2) Question 6-8 is Health Benefit, (3) Question 9-12 is a question of Benefits to the economy, (4) Question number 13 is a question related to Benefit to society directly. 
All respondents know clearly about the company PT AQUA Golden Mississppi which is an AMDK company that has been acquired with DANONE from France. Then on the question related to public health, all respondents explicitly explained what the local government got from the AQUA Golden Mississippi CSR program in addition to the WASH Program, among others: greening, road repairs, made habitable homes, orphanage assistance, has spread to several villages in Cicurug district. On questions related to the economy in the area, all respondents also responded casually and stated that the government got PAD (district's revenue), PMDN (domestic investment), PMA (foreign investment), but the most important is the presence of PT AQUA Golden Mississippi in the area increasingly grows the economic and community income.

In short, Mekarsari is the location closest to the PT AQUA Plant, even before the CSR program in 2006, PT AQUA has actively participated in the communities around Mekarsari who have no toilets, so the response that the author gets in the area is very positive, declared the company to be doubtful, as from the time of PT AQUA originated, many of them claimed that PT AQUA came from France, while Danone came from Indonesia. However, based on the level of satisfaction of Mekarsari society to PT AQUA, the author dared to argue that 9 out of 10 people living in that area are greatly assisted by PT AQUA, not only in terms of infrastructure growth but also health during drought, PT AQUA is responsive in helping people who have submitted proposals to be assisted.

The source of information that the writer get in Benda of which we interview the most respondents in our research. There are 24 respondents consist of traders (13), housewife (2), student (8), and security officer (1). As we hypothezed, there is a positive response from 24 respondents in the village. This is because PT AQUA is helping the village of Benda in overcoming the prolonged drought, the response given by PT AQUA is also prompt. In Cicurug district, Sukabumi this program is run in a number of local neighborhood. This is because the company deliberatively helps local people who feel the clean water crisis.

At the same time, the author also meets with Local Officers of Benda, Aang Gunaipi (Chairman of RT 3), and HM Andi Mulyasana S.E (Head of the Village). There are at least 12 interview questions of which we divide into four main categories: (1) Question 1-5 is Corporate introduction, (2) Question 6-8 is Health Benefit, (3) Question 9-11 is a question of Benefits to the economy, (4) Question number 12 is a question pertaining to Benefit to society directly.

In the first category, the respondent understood that PT AQUA Golden Mississippi produced AMDK, and Galon, and had made an acquisition with DANONE from France. On the second category, the respondent does not know exactly how much PAD, PMDN, PMA obtained from PT AQUA Golden Mississipi, but she tells how WASH happened in Benda village which has experienced long drought in the area. Therefore, the local government that has cooperated with KOTAKU (City Without Slums) and get assistance of 250 million rupiah in 2015 ago, but access to clean water is still not enough to all areas in Benda village, then local government submitted a proposal to PT AQUA in October 2016, and was responded seriously by PT AQUA two months later. PT AQUA then spent approximately 146 million rupiah to Benda village. This AQUA program successfully built MCS (Bath, Wash, Kakus) facilities in a number of villages, such as Benda village, Nanggerang, etc. However, on the other hand there are no people from Desa Benda hired PT Golden Mississippi. This is because the company has met the workers quota.

From the theory of triple bottom line we can conclude that, in the context of People aspect, a company founded by a human worker. In other words, the company must be socially responsible both inside and outside the company. The main focus of the establishment of a company is human, and society. These responsibilities have an impact on the development of the company by providing a good environment between communities and companies by providing activities that support people's lives. Therefore, PT AQUA Golden Mississippi creates at least three CSR programs, namely WASH, Conservation and Economic Development that create good relationships between companies and communities, these relationships not only bring together benefits, but also good for the sustainability of the company in the future.

In the Planet aspect, in the present day, usually environmental damage is caused by the existence of a company in a region, therefore every society that is connected directly or indirectly with the company need the benefit derived from natural resources. It is this that encourages companies to participate actively in safeguarding and improving the natural environment, not just the exploitation of natural resources for the sake of profit. Therefore, PT AQUA Golden Mississippi actively conserves the environment, by planting trees in surrounding mountains, and repairing damaged roads, so that the company not only maintains good relations with the community, but also the surrounding environment.

On the Profit aspect, the basic purpose of establishing a company somewhere is profit. Profit is the main key that can bridge between a business. However, in order to ensure that the company is sustained, the company is required to provide care for environmental concerns around the company (Elkington, 1997, 71). This is because the People and the Planet will not be done if a business does not have a profit. In other words, with the presence of PT AQUA Golden Mississippi should maintain good relations with stakeholders, so it can affect the company's economy, such as getting workers who live around the factory, thus reducing production costs, create better product quality, have a good image to the company, and have long-term relationships with stakeholders.

Based on its circles of sustainability theory, PT AQUA Golden Mississippi, helps in the areas of:

1) Environment, which means the company is responsible for the environment located around the company.

2) Food, which means that a good company will make the surrounding people not starve. In other words, such as providing jobs for the surrounding community.

3) Health, which means a good company will pay attention to the health of the employees and the surrounding community. Like the WASH program that has been running since 2006 in various locations in Sukabumi, Cicurug. 
4) Education, the company should also pay attention to the next generation in the area surrounding the company. Especially in children of company employees who enter into the category of less able.

5) Empowerment is needed as a philosophy plan in improving the quality of work life for employees (Lincoln, Travers, Ackers, and Wilkinson, 2002), such as the existence of capital assistance provided to MSMEs, which is then distributed to the community, help later.

Therefore, for a company, sustainability means an anticipation of how the economic, political, and ecological systems can dictate market conditions over a longer period of time. Thus, this approach offers methods for solving important environmental related issues.

\section{CONCLUSION}

This research revealed that implementation of triple bottom line theory and sustainability theory in PT AQUA Golden Mississippi CSR program can be measured based on indicator of activity type and sustainability principle, and its benefit for stakeholders. This research found that Aqua is a MNC with the home country is DANONE with shares majority located in France. DANONE and AQUA are strategic partners that have a motive for market seekers and resources seekers. By using triple bottom line theory and circles of sustainability theory, the integration of corporate strategy and sustainability development of the society has succeeded and is satisfactory.

Share values between old and new workers by cooperating in the development community program into change management and transformation of post-acquisition management. Implementation of CSR conducted by PT AQUA Golden Mississipi especially WASH (Water Access, Sanitation, Hygiene Program) that helps support at least 18,500 people around the factory, where they have to submit proposal to the company first. The impact of these WASH programs get a positive impression on the people of Mekarsari, Benda, Nanggerang, Nyangkowek, Purwasari, and Caringin. On the other hand there are some villages that feel less satisfied or do not get help from companies like Cicurug, Bangbajang, and Tenjoayu.

PT AQUA Golden Mississippi positively implements the triple bottom line and circle of sustainability theory towards public health around Mekarsari factory, Sukabumi. Responsibility for the Economy (Profit) of PT AQUA Golden Mississippi can be seen from the number of buyers who always always buy and trust AQUA products as a selection of AMDK (Bottled Drinking Water), and gallons. The Responsibility for the Environment (Planet) of PT AQUA Golden Mississippi can be seen from three CSR programs, namely WASH (Water channel), Conservation (Making absorption wells, biopori, and tree planting), and Economy Development). Social responsibility (People) is actually implemented by the company through a series of CSR activities involving the community in the field of environment, health, food, education, and empowerment of communities around the factory, by conducting a series of CSR programs, such as WASH (clean water channel), Conservation Making absorption wells, biopori, and tree planting), and Economy Development (in the form of capital to MSMEs).

\section{REFERENCES}

[1] AQUA Website. 2017. Sejarah perkembangan AQUA: Nilai Luhur - Perjalanan AQUA dari Tahun ke Tahun. Retrieved http://www.aqua.com/tentang_aqua/nilai-luhur

[2] Bardy, R. , Drew, S., and Kennedy, T.F. 2012 "Foreign Investment and Ethics: How to Contribute to Social Responsibility by Doing Business in Less-Developed Countries". Journal of Business Ethics, Vol. 106, No. 3 (March 2012), pp. 267-282 Published by: Springer Stable URL: http://www.jstor.org/stable/41426690

[3] Bhattacharya, C.B., Sen, S,. and Korschun, D. 2012. Leveraging Corporate Responsibility: The Stakeholder Route to Maximizing Business and Social Value. Cambridge: Cambridge University Press

[4] Birkinshaw, J,. And Bresman, H., 2000 "Managing The Post-Acquisition Integration Process: How The Human Integration And Task Integration Processes Interact To Foster Value Creation". Journal of Management Studies 37:3, Stockholm School of Economics L, University of Linz

[5] Cohen, S. 2007. Multinational Corporations and Foreign Direct Investment: Avoiding Simplicity, Embracing Complexity. Oxford: Oxford University Press. pp. 8.

[6] Dunning, J.H., and Lundan, S.M. (eds.), 2008. Multinational Entreprises and The Global Economy. 2nd ed. Edward Elgar Inc.

[7] Freeman, E., Velamuri,. S.R., 2002 "A New Approach to CSR: Company Stakeholder Responsibility" New York: Palgrave Macmillan

[8] Fontaine, Michael PhD. 2013. "Corporate Social Responsibility and Sustainability: The New Bottom Line?" International Journal of Business and Social Science Vol. 4 National Louis University

[9] Gherghina, S.C., and Simionescu, L.N. 2015. Does Entrepreneurship and Corporate Social Responsibility Act as Catalyst towards Firm Performance and Brand Value? in International Journal of Economics and Finance Issues; 7 (4)

[10] Haines, A., Cassels, A,. 2004 'Can the millennium development goals be attained? retrieved from https://www.ncbi.nlm.nih.gov/pmc/articles/PMC509351 /

[11] Hemingway, C,. and Maclagan, P.W,. 2004. "Managers' Personal Values as Drivers of Corporate Social Responsibility Author" Journal of Business Ethics, Vol. 50, No. 1 (Mar., 2004), pp. 33-44 Published by: Springer Stable URL: http://www.jstor.org/stable/25123191 .

[12] Jenkins, Willis. 2010. "Berkshire Encyclopedia of Sustainability 1/10: The Spirit of Sustainability" Available http://www.berkshirepublishing.com/assets_news/sustai nability/Spirit_SustainabilityTheory.pdf. YYale Divinity School

[13] Kegley, C.W. and Wittkopf, E.R. eds., 1988. World Politics Trend and Transformation. 3th ed. New York: ST Martin's Press

[14] Robins, Ron. 2015. Does Corporate Social Responsibility Increase $\quad$ Profits?. ethics.com/2015/05/05/does-corporate-socialresponsibility-increase-profits/

[15] Schneider, F., Frey, B. 1985. "Economic and political determinants of foreign direct investment". World Development, Vol. 13, No. 2, pp. 161-175

[16] Theodosiou, M., Leonidou., Leonidas. C., 2002. "Standardization versus Adaptation of International Marketing Strategy: an Integrative Assessment of the Empirical Research". International Business Review, 12 (2003) 141-171 
[17] UNTAD, Inc., 2017. World Investment Report 2017Investment and Digital Economy. Retrieved from http:// FDI/MNE database (www.unctad.org/fdistatistics)
[18] http://marketeers.com/industri-air-minum-di-indonesiatak-pernah-paceklik/ 